\title{
DIGITAL TRANSGRESSIONS: FICTION AND CHANGE IN THE ERA OF TECHNOLOGICAL EXPANSION
}

\begin{abstract}
Although the challenges that authors have had to face in their attempts to articulate their intimate and public (hi)stories happen to be much older than computers, it was digital technology that offered a miraculously effective existential and fictional frame for the mediation of literary testimonies. The fictional realism of the digital age is constructed around a newly formed class of young or middle-aged individuals most willing to adapt to a technology-centred civilisation and to a seismic technological change. The paper focuses on various forms of digital existence in contemporary fiction writing with the intention to illustrate crucial changes in the concept of reality and writers' concern with the fidelity to experience. The surge of the so-called digital realism coincides with the revelation that the otherwise thin line between our digital personas and our real-world selves has grown obscure and even more difficult to detect, while new technologies are required to go beyond what our human senses can encompass and deliver.

The paper intends to examine the ways new digital technologies contribute to representations of reality in the novels by Amber Tamblyn, Tamara Jecić, Mihajlo Spasojević and Aleksandar Ilić, all of them aspiring authors whose novels deal with ways of life amid social networks and digital technologies. Stalking friends and foes on Facebook and Instagram, starting
\end{abstract}

vladislava.gordic.petkovic@ff.uns.ac.rs

The paper is the result of research conducted within project Languages and Cultures across Time and Space [ON 178002] funded by the Ministry of Education, Science and Technological Development of the Republic of Serbia.

This paper was submitted on August $25^{\text {th }}, 2019$ and accepted for publication at the meeting of the Editorial Board held on September $16^{\text {th }}, 2019$. 
relationships online and pursuing boundless obsession with multiplicity of identity are among complex issues these novels deal with, capturing the voices at the margins and letting the characters transcend their real-life grounded identities. The novels show that the gap dividing the virtual and the (corpo)real world narrows, as their narratives range from intimate confession in letters and journals to blog posts, tweets, and statuses, introducing verbal and structural experimental practices which involve shifting points of view.

KEYWORDS: technology; narrative; realism; culture; media.

\section{TRANSGRESSIONS OF REALISM}

Abrupt historical changes have always called for cautious and gradual shift of interpretational strategies and priorities. In his groundbreaking and widely cited essay "The Storyteller: Reflections on the Works of Nikolai Leskov" (1936), Walter Benjamin tries to find out what kind of collective experience might replace the solitary appreciation (Benjamin, 2006, p. 362), whereas in 1970 Alvin Toffler coins the phrase "futureshock" in order to describe the mental condition of individuals who face enormous changes in a short period of time. Addressing the issue of digital ontology, Justin Clemens and Adam Nash note that it means that "the digital literally enacts a form of paraconsistency, simultaneously constituting and being constituted by it" (Lagerkvist, 2018, p. 35). According to Azade Seyhan, our critical terms for literary study are not adequate for an exploration of the transfigurations we encounter in the world we inhabit: "The emergent literatures of deterritorialized peoples and literary studies beyond the confines of national literature paradigms have as yet had no name or configuration" (Seyhan, 2001 , p. 9). This is the reason why a substantially altered strategic approach is needed when we discuss the writing in the age of fast changing technologies. Technology has deeply affected the ways how we interact, introducing new strategies to redefine privacy and unwanted mechanisms to compromise it, amongst other things.

What has also undergone transfigurations and redefinitions is realism, a much-abused word, as George Orwell observed seventy-five years ago. Although back in the past the genre was not always greeted enthusiastically by public and critics, it continues to transform into new, viable forms up to now. "A 'realistic' novel is 
one in which the dialogue is colloquial and physical objects are described in such a way that you visualize them" (Orwell, 1970, p. 282). Realism in literature was introduced as a representation of the consciousness specific for an emerging modern world, with fidelity to experience as its leading principle. What the traditional realistic novel realizes in its narrative is the profound epistemological and ontological revolution announced by philosophers such as Locke, Descartes or Spinoza, who see that reality is grounded in sense perception and quotidian experience (Richetti, 1999, p. 3). According to Ian Watt, one of the groundbreaking literary historians, "the novel is a full and authentic report of human experience", "under an obligation to satisfy its reader with (...) details which are presented through a more largely referential use of language than is common in other literary forms" (Watt, 1957, p. 32). According to Watt, the form of the novel's primary criterion is "truth to individual experience" (Watt, 1957, p. 13). Orwell observes that "the describing of everyday scenes and the construction of natural-sounding dialogue are largely a matter of technical tricks which are passed on from one generation to another, gradually improving in the process" (Orwell, 1970, p. 284). The realism in the novels by Daniel Defoe, Tobias Smollett and Samuel Richardson demonstrated a pragmatic and empirical understanding of life and human behaviour, recognizing human individuality, knowledge and experience.

Classical realism of the eighteenth and nineteenth centuries depicted the identity as fixed and unchangeable, treating it as an element in a given system of differences which is human nature and the world of human experience (Belsey, 1980, p. 90). The change occurs when contemporary literature has turned the intersubjective moment into an interactive one, expanding the range of characters' experience deep into the sphere of virtual communication. A new surge of digital realism in literature coincides with the increase of awareness that the line between our digital selves and our corporeal, "real-world" selves has become unclear and impossible to regulate, whereas the new technologies are required "to go beyond what our human senses can encompass and deliver" (Gordić, 2017, p. 96). If the narrative realizes that reality is somewhere beyond the perception of the senses, it does not necessarily mean that the representation of it assumes the existence of a tangible external "reality". 
The concept of reality can be understood much better when we take into account the metaphor Jane Austen used when she discussed the technique and the scope of her novels: when developing plots which invariably dealt with country families occupied in marrying off their children, cousins and relatives, she focused on the narrative strategies with almost unnoticeable impact. Austen described her text as a tiny piece of ivory and her technique as a delicate brush: "the little bit (two Inches wide) of Ivory on which I work with so fine a Brush, as produces little effect after much labour" (qtd. in Chapman, 1959, p. 299). Although her artistic principle seems to be deliberately understated and simplified in such an unpretentious explanation as this one is, Austen becomes a good example to demonstrate that realistic novel is always dealing with what might be called the principal social and material concern of a particular class: in the imagined worlds she depicts there is hardly ever a noticeable change.

The new technologies have readapted and reinforced systems for capturing the multitude of voices situated at the margins of social communities, and cyberspace has invented new strategies to transcend our grounded identities. This transformation became necessary for the environment of the new media and their capacity to represent a virtual entity, which has proved as an enticing possibility to transgress restrictions. The challenges that authors have had to face in their attempt to create and circulate their intimate and public histories are much older than computers and informational highways. The daily routine in a postmillennial reality has come to encompass a multitude of intersecting empirical and virtual planes of existence: life, work and relationships develop in a dimension where geography and physical barriers have been largely ignored, which results in many alterations in "concepts of time and space, as well the concepts of privacy and intimacy" (Gordić, 2017, p. 96). Although "technology-centered civilization has given birth to numerous global problems, caused not only by the development of technology but also by the usage of it in terms of affecting man's habitat" (Malkova, 2018, p. 856), among those problems being "educational, psychological, communicative" (Malkova, 2018, p. 856), optimism prevails, at least until the individual affronts the impasses of his or her emotional growth.

For one thing, the dating landscape changes with the advent of the new technologies, so that the ways love is perceived and experienced change as well. As another kind of collective experience 
which replaces solitary appreciation, social networking has become a verified strategy in literature, television and film, convenient enough to reflect the character's growth in a sex-obsessed culture, in which young people are "forced to navigate a minefield more challenging, and pressure-filled than ever before when it comes to one vital topic: sex" (Platt Liebau, 2007, 10). Being sexy has become "the ultimate accolade" (Platt Liebau, 2007, p. 14) and the pervasiveness of sex in today's culture has left a considerable imprint on young people, leaving their parents unable to react in the proper way against what Carol Liebau fretfully calls "the decline of decency". Present times are characterized, due to digital technologies used for creating and communicating virtually universally available information, by an "uncertain" relation with information, seen as the most important resource and treasure in many realms of life. Networking started as a social activity which clearly responds to the need of new media technology users to focus on important events in their everyday life and to elicit an appropriate response from the audience they targeted. Communicative practices in social networking show that our virtual identities continue to vacillate between public and private, but also between use and misuse.

TRAUMA, PAIN AND THE MEDIA: AMBER TAMBLYN

Amber Tamblyn's debut novel Any Man, a dark piece of experimental fragmented fiction about a female serial rapist, gives voice to six men healing after the sexual predator called Maude destroys their bodies and leaves them naked in the humiliation of her abuse, with a six-foot long, white hair left as the only proof of her presence. Maude is both a brutal human assailant and a deformed mythical creature, and her victims can perceive only fragments of her body or slight signs of her presence: black eyes, misshapen hand or breath like rotting fish. Instead of focusing on the transformation of the victim, Tamblyn suggests that the repetitive act of inflicting pain becomes a transfiguring process for the perpetrator: Maude transforms into a monster during the very act of killing or mutilating her male victims. The origin of her crime and the roots of her hatred for her victims remain unclear, or lost in the fragments of facts and visions mediated by technology. The narrative voice in the novel focuses on interior monologues of the survivors, their correspondence with one another and on media echoes coming 
from the TV and the Internet, demonstrating how the society readily finds entertainment and even enjoyment in the pain of the victims of sexual assault. Tamblyn insists on placing the blame on the media for the way they relish in pain and horror of the men attacked by Maude: publicizing the crime and celebritising the grief are motifs minutely observed within a community which cannot resist any of the two urges.

Tamblyn's decision to make the rapist a woman and to write from the point of view of the rapist's six male victims has upset some readers, but her intention was not just to reverse gender roles. The author, herself a Hollywood star, an accomplished poet and one of the founders of "Time's Up", the organisation launched at the beginning of 2018 to fight sexual harassment in the film industry, was much more focused on provoking the interest into the rape culture and the ways sexual assault is addressed. Tamblyn felt that the \#MeToo movement was too much focused on white, upper class women, ignoring the underprivileged women and male victims alike, and that is one of the reasons she decided "to show the violence of objectification; the physical and psychological violence of assault; the violence of not being believed" (Mahdawi, 2018). The novel is experimentally formatted, using prose, poetry, soliloquies, emails, online chat and tweets to tell the story. Tamblyn is mapping the discursive media strategies which are used to publicize rape with the intention to focus on the pain and the trauma the victims relive in their imagination. Any Man blends genres of journal entries, radio shows dialogue, dating app chats, monologues and erratic thoughts, and elements of suspense to shape the shocking narratives of victims of sexual violence. The survivors all have to deal with the disbelief thrown at them that even a man can be raped, as well as with the media endlessly speculating about them as victims and the part they played in their own attack. The victims are shamed and even ridiculed: the aftermath unleashes a whole new hell after the initial crime, and that is just one aspect of their suffering; deep inside, the characters are also faced with humiliation, fear and feelings of disgust with themselves. The schoolteacher from Watertown Donald Ellis reveals his dismay in a row of interior monologues:

I talk about the walking shoes I just purchased, the best brands of mosquito repellent, the time I was mutilated and left for dead in an alley, the time I went rafting with friends for my forty-sixth birthday. I do not talk. I do not talk. (...) I do not talk. Or I talk about the effects 
of wind on different sizes of birds. I talk about taxidermy. I talk about golf. (Tamblyn, 2018, pp. 34-35)

Dealing with pain and shame makes the reality of the world change:

The human smile no longer makes sense to me. Why is it a sign of happiness? Who decided that? Why not the crinkling of the nose, or blinking, or a hard swallow? Who invented the word smile and gave it its meaning? (...) Smile is the shape of my mouth my therapist looks for when she asks how I'm doing. It is the shape of my mouth Camilla wants to kiss when I return from a day's work. The shape of my mouth my neighbors and colleagues desire to set them at ease. It makes others feel safe with my story. I practice this smiling, this mouth's shaping, in the mirror. I do it for them. (Tamblyn, 2018, pp. 37-38)

Menacing and impossible to subdue, Maude is also present in the cyberspace, praying on her victims, using the nick JasmineRose while chatting with Jamar Sands (Jamarvelous83) and other victims. Her invincibility is partly due to the fact that the press in enchanted with her: when a journalist contacts Maude, the tone of his message demonstrates an alarming combination of investigative journalism, sensationalism and pop psychology:

JOSHUA_DISPATCH: Dear Maude, my name is Joshua Greenfield and I am a reporter with the Dispatch newspaper. In the event you ever check this OkCupid account again, we would love to get a statement or comment from you regarding your relationship with Jamar Sands, Donald Ellis, or Pear O'Sullivan. Specifically, we would love to hear from you directly regarding your motives. Perhaps one of these men did something to you at one point? Perhaps you have your own history with violent men? Were you yourself ever sexually abused or harmed? Anything you'd like to share with us would be greatly appreciated and would be printed verbatim. (Tamblyn, 2018, p. 135)

Maude is an ever-present menace, hunting for her preys both online and offline, assuming many shapes, voices and identities, thus representing the omnipresence of evil which no digital existence can erase or remedy. Her victims are humiliated by the ways they must affront the aftermath of their assault: they are exposed to disbelief and doubts from the police, feelings of shame overcome them and alienate them from their family and friends. What makes their suffering much stronger is the fact that their pain is being publicly dissected. Maude thus becomes a loaded figure which emanates the 
society's fears and fascinations, passion and misogyny. What is extraordinary about the novel is how as years pass these men learn to heal, by banding together and finding a space to raise their voices. Told in alternating viewpoints signature to each voice and experience of the victim, Any Man is a narrative filled with emotion, ranging from abominable fear to heartfelt empathy.

\section{TECHNOLOGY AND TEMPTATIONS: DISPLACING SERBIAN FICTION}

It is a quite recent trend in Serbian fiction to accept the computer mediated communication as an interaction occurring in an entirely different environment, in a context visibly changed with the advent of tablets, smart phones, hyperlinks and applications. Several new thirtysomething Serbian novelists follow in the footsteps of the predecessors whose novels tackled various issues related to digital ontology or interaction transgressing boundaries of previously practiced social mores. Some authors born in the 1950's, such as Mileta Prodanović, Jelena Lengold, and Đorđe Pisarev have, all of their own accord, struggled to articulate narrative strategies that could channel their ultimate desire to share the most intimate concerns with the reader.

Technology offers some viable solutions to deal with both the temptations of society and history. When reflected in literature, the civil wars in Yugoslavia demanded a new approach to the issues of rootlessness and uprootedness, but they also offered a chance to discuss the displaced characters with the help of technology. One of the most important motifs within this theme became the displacement from one's native country and the estrangement from the culture one was born and raised in. Probably the first Serbian novel that tackles the issue of cyberspace and virtual identities while associating them both with Otherness and exile is Stinky Onion by Tamara Jecić. The anonymous main character's lonely life and yearning for intimacy are documented by his contemplation, recollections, dreams, as well as his Internet activities such as chatting and texting with strangers who might offer a temporary solace. The reader immediately understands why the protagonist of Jecić's fictional autobiography, a thirty-something USA immigrant from Serbia, introduces himself as an "Indian", living on the territory 
Native Americans lost. The city of Chicago used to be called Stinky Onion by the tribes which lived on the soil, so that the name becomes a common identifier for the history of displacements which includes the Serbian immigrant who belongs to "the underpaid working class, whose degree and knowledge is not needed here" (Jecić, 2009, p. 48). The self-proclaimed Indian introduces himself as a person expected to work hard and achieve a little: "I, too am the one who is expected to be happy when given any job and who will grin and bear it, work, pay taxes at the end of the year, and when the time comes, vote for one of two provided presidential candidates" (Jecić, 2009, p. 48).

His first interaction with the loneliness in The New World occurs at the airport, owing to one of his odd jobs: the Indian works as a wheelchair assistant, which signals an ironic, inverted parallel to his own helplessness. The conventional exchange with his customers, mostly the elderly passengers in transit, serves as an introduction into his further futile search for intimacy in the cyberspace. The airport instils in him the feeling of the so called "non-place" which is to follow him throughout his life in the USA. Stinky Onion turns out to be a non-place both to the protagonist and to the ex-Yugoslavian diaspora, linked to cyberspace as another site of reinvention and restoring of one's identity. Marc Augé coined the phrase "non-place" as a reference to places of transience that do not hold enough significance to be regarded as proper places (Augé, 1995 , p. 10), such as a motorway, a hotel room, an airport or a supermarket, and it is sensible to presume that the Internet can be seen as a non-place as well, due to its lack of substance and constancy, owing to its endless capacity to mirror our fears and desires, as well as temporarily fulfil them. This vast network of data does not frighten the characters ready to dive into the digital reality; it rather seduces and invites them, as we shall see in several examples.

"In producing his localization, the Indian redefines his collective and personal identity by negotiating his sense of belonging to many different communities, spatial and virtual" (Marić, 2013, p. 134). The protagonist's identity construction is challenged by computer-mediated communication, and the potential of this technology seems limitless at first, but very quickly turns into an inescapable addiction, which is "stronger than meeting real, live people" (Jecić, 2009 , p. 68). The Indian starts looking for online companionship, driven by the hunger he classifies as intellectual, emotional, and 
sexual. The cyberspace allows him to be simultaneously present and absent, as well as to simulate an otherwise non-existent social life, renounce the hidden traumas and troublesome past. Digital technologies open an opportunity to consumers to reinvent themselves through language and narrative, promising new freedom and independence to the participants in discourse who interact socially while still living a drab, solitary life. The unnamed narrator of Stinky Onion finally resigns to the idea that his depression will never go away, but he keeps on looking for the ways to resolve his dilemmas either through computer-mediated communication or in creating a narrative which mirrors the chaos and entropy of everyday life. Risking another emotional turmoil after numerous shocks and defeats, the protagonist bravely gives in to search for self-identity in an inconsistent and volatile world, fighting a hopeless battle against despair.

Contemporary novels which deal with technology show that any ordinary life can be lived not only within the social environment, but also in the realm of social networks. Narratives presenting digital reality range from intimate confession in letters and journals to social interactions in the forms of chats, tweets and Facebook posts, introducing experimental practices which include shifting points of view, stream-of-consciousness technique, and various typographical experiments. Digital technology offered a solid existential and fictional frame for the mediation of various kinds of testimonies as it emulates immediacy much better than the traditional narrative techniques.

In his Kafkaesque novel A Clueless Man (Čovek koji nije imao pojma) Serbian writer Mihajlo Spasojević casts a grotesque and sardonic dystopian tale about a high school in Bronx where students publicly shame their professors by stalking them, posting their photos to Facebook, recording their awkward moments or by labelling them as "gay" just because they do not possess the brand new model of a cell phone. This funny and frightening parable about dismal perspectives of education focuses on pessimistic prospects of using technology in classroom or digital technology being the easiest explanation for the alarming lack of interaction between the protagonist (called simply professor S.) and his unruly students, as much as it tackles impasses in the educational system. Education and culture seem to have moved with the help of technology far from modern archives such as museums and galleries, to post-modern archives like the broadcast television systems and then to net- 
work archives, like the global digital network, but no newly invented strategies manage to arouse the interest of young students to embrace knowledge. Professor S. has not enough nerve to fight his students' ignorance and lack of motivation, and he becomes a sad symbol of the older generation losing the battle to preserve traditional values and priorities.

The critique of capitalism and modern school system subtly averts the reader's attention from the impractical and clumsy Professor S, as the novel gradually gives in to a futuristic fantasy about the iron fist of the bureaucracy which finally prevails over the agendas of independent individuals. Spasojević's novel focuses on impoverished lives of indifferent youngsters whose lack of motivation is encouraged with attractive gadgets enabling them to share cheap thrills and superficial excitations. The author demonstrates how meaningless and estranged life becomes when the social networks turn into the chief communication device by the very refusal to cast a proper character study of his main character. Digital reality is not concerned with delayed responses, contemplation or digging deep to find suppressed traumas and hidden motives: Professor S. cannot ever become a complex character since he is dwindled down by his own environment and its harmful impact. His distorted vision of reality comes from the distorted society itself: the school principal, mockingly called Her Principality, insists that "our children need inspiration, role models!" adding that "our schools need another, another brand new narrative!" (Spasojević, 2014, pp. 3-4), but she is at a loss for what to do to fulfil these goals.

Describing a young man's career in a cubicle of an advertising agency against the backdrop of a tumultuous love affair with his co-worker, Aleksandar Ilić's novel PR introduces a disoriented and distracted hero whose daily life revolves around interacting on the social networks and juggling with mobile phone applications. The premise that more communication vehicles mean more audiences but also an increasing risk of fragmented consumption of information is best demonstrated in the case of the unnamed protagonist, who interacts with many people online, sharing his grief with some of them after the breakup with his lover Sonja, but no close friendship or ensuing offline interaction result from this. His virtual friend that goes under the name Anna from the Wonderland seems to be of help during his emotional crisis, but her tips for a better life soon start to sound as bland as those coming from self-help books 
on depression. The life filled with advertising messages coming in various forms and shapes, text notifications popping from computer and mobile devices and online banners displayed on screen denies any chance that a loyal friendship or true love might grow out of random contacts, and the protagonist's lover will finally move away from the virtual world in order to fulfil her expectations elsewhere. Sonja will end the workplace romance, leaving the protagonist in despair and dejection which are mostly an outcome of wrongly chosen priorities and trading real life experiences for simulacra, as we can see in his vision of the afterlife:

I believe there is no heaven, and that we should build it. I envision it as a gigantic server with an endless multitude of hard discs where it is possible to upload everything we take to be mental or spiritual: memories, emotions, or ideas. That heaven is digital and immortal digital people inhabit it, living in folders instead of houses made of bricks and concrete, with browsers instead of windows and antivirus programs instead of vacuum cleaners and hospitals. I picture myself signing in to my Facebook profile from one of these servers after my body has died; or I blog, chat with my offspring that will be born in a thousand years or divorce my wife and divide our folder in two. (Ilić, 2014, p. 209)

With Sonja at his side or without her, the protagonist's life is reduced to aimless interactions with virtual friends on Google Hangout, Skype or Facebook, getting stoned, playing computer games and indulging in sexual fantasies. With the revolving issues of casual sex and repetitive discussions with few dysfunctional friends, the deadpan narrative voice resembles the catatonic, indifferent voices from Brett Easton Ellis's Less Than Zero and Rules of Attraction, but is also similar to Raymond Carver's characters' testimonies about lives burnt-out with alcohol and disappointment.

\section{CONCLUDING REMARKS: POST2000, POSTWHAT?}

The reductive, catatonic idiom of Spasojević's A Clueless Man and Aleksandar Ilićs $P R$ becomes functional in characterization not because the protagonists are traumatized or emotionally damaged like Tamblyn's: they actually adapt to the habitual mode of expressing oneself that is prevalent in their environment. They adopt, either intentionally or unwittingly, interactive manners of the advertising industry as well as the codes of communication on 
social networks which verify their pose of aloof existence. The post-2000 sensibility seems to be adjusted to minimalist communication as much as to relentless sexual liberation. Still, the pressures of patriarchy and consumerism continue, and cannot stop meddling in the socially acceptable modes of living. Promiscuity and adultery happen against a cultural landscape where the rules of heterosexual relations are in a state of flux, rendering both men and women unsure and ignorant about what is expected of them in public and private spheres. Faced with an independent and even relentless woman, hegemonic masculinity repositions itself as an unstable identity in need of redefinition. As a result, the formula for the ideal romantic hero has become imprecise, forcing the young generations to look for new ways of self-development, such as digital formats of communication and embracing new social practices in life and literature alike.

Tamblyn introduces a fictional reality in which both the human body, the pain inflicted to it and the social media treatment of the victim's suffering become an indissoluble testimony of present times. The digital realism of Tamara Jecić and Aleksandar Ilić promises to be much more than a slight and unmeaningful alteration of the realistic strategies known as verism or minimalism, turning the digital media interaction into a harbinger of the new artistic sensibility, promising to influence the discourse of the realistic novel and change the currents of narrative practices.

\footnotetext{
REFERENCES Augé, M. (1995). Non-Places: Introduction to an Anthropology of Supermodernity. Translated by John Howe. London, New York: Verso.

Belsey, C. (1980). Critical Practice. London and New York: Routledge.

Benjamin, W. (2006). The Storyteller: Reflections on the Works of Nikolai Leskov. In: D. Hale (ed.), The Novel: An Anthology of Criticism and Theory 1900-2000 (362-378). Malden, Mass.: Blackwell Publishing.

Chapman, R. W. (ed.). (1959). Jane Austen's Letters to Her Sister Cassandra and Others. London: Oxford University Press.

Gordić Petković, V. (2017). Motiv virtuelne egzistencije u savremenom srpskom romanu. Zbornik radova Filozofskog fakulteta u Prištini, 47 (1), 85-96.

Ilić, A. (2014). PR. Beograd: Laguna.

Jecić, T. (2009). Stinky Onion. Beograd: Narodna knjiga.

Lagerkvist, A. (2018). Digital Existence: Ontology, Ethics and Transcendence in Digital Culture. New York: Routledge.
} 
Mahdawi, A. (2018). Why write a Novel about a Brutal Female Rapist in the Age of \#MeToo? Amber Tamblyn Explains. The Guardian, July 2.

Malkova, T. (2018). Philosophy of Technology: Modern Technological Reality and the Regularities of Development. In: Advances in Social Science, Education and Humanities Research, Vol. 283, pp. 856-859. Paris: Atlantis Press.

Marić, I. (2013). Globalization, Identity, Commodity: The Case of Stinky Onion (Tamara Jecić) and The Penultimate Journey (Gordana Ćirjanić). Kultura, 45 (138), 130-143.

Orwell, G. (1970). Tobias Smollett: Scotland's Best Novelist. In: Collected Essays, Journalism and Letters, Vol. 3, pp. 282-286. Harmondsworth: Penguin.

Platt Liebau, C. (2007). Prude: How the Sex-Obsessed Culture Damages Girls (and America, Too!). New York, Boston, Nashville: Center Street.

Richetti, J. (1999). The English Novel in History 1700-1780. London and New York: Routledge.

Seyhan, A. (2001). Writing Outside the Nation. Princeton, N. J.: Princeton University Press.

Spasojević, M. (2014). Čovek koji nije imao pojma. Beograd: Rende.

Tamblyn, A. (2018). Any Man. New York: Harper Collins.

Watt, I. (1957). The Rise of the Novel: Studies in Defoe, Richardson and Fielding. Berkeley and Los Angeles: University of California Press.

ВЛАДИСЛАВА С. ГОРДИЋ ПЕТКОВИЋ

УНИВЕРЗИТЕТ У НОВОМ САДУ

ФИЛОЗОФСКИ ФАКУЛТЕТ

ОДСЕК ЗА АНГЛИСТИКУ

РЕЗИМЕ

ДИГИТАЛНА ТРАНСГРЕСИЈА: ПРОЗА И ПРОМЕНЕ

У ДОБУ ТЕХНОЛОШКЕ ЕКСПАНЗИЈЕ

Тематски трендови у постмиленијумској српској прози сведоче да полиглосија друштвених мрежа отвара ново подручје инспирације. Стога се јавља потреба да се пажљиво анализира присуство технологије у савременом роману и да се преиспитају промене у приступу реалистичком приповедном поступку и његовом дефинисању. Приметни су напори и код читалаца и код теоретичара да се у нову дефиницију реалистичког укључе сви аспекти дигиталне димензије свакодневице, односно свест о различитим концепцијама упоредних светова: света емпиријске и света виртуелне реалности. 
Основе дигиталног реализма у књижевности утемељене су у сазнању да је граница између наших виртуелних и реалних идентитета нејасна и тешко одредива, упркос томе што желимо да их раздвојимо. Комуникација у сфери друштвених мрежа постаје дневна рутина, па тако окружење у роману Stinky Onion Taмаре Јецић уз географску и културну укључује и виртуелну димензију, која подразумева стварање нових веза и са перспективом живота у страном свету, и са трауматичном прошлошћу домовине. Михајло Спасојевић у роману Човек који није имао ӣојма са критичке дистанце предочава природу и функцију технолошких достигнућа, која у контексту механицистичке, до апсурда бирократизоване педагогије губе на значају и применљивости. Критика либералног капитализма, неефикасног школског система и неодговорног односа према младима видљива је у гротескној интеракцији Спасојевићевог јунака професора С. са колегама и ученицима, док Александар Илић у роману ПР као легитиман мизансцен користи садржаје са Инстаграма и „дигиторалну“ комуникацију са клијентима маркетиншке агенције, пошто његови јунаци усвајају интерактивне манире света адвертајзинга. Амбер Тамблин у дебитантском роману Било који муuкарац комбинује епистоларну технику, исповест и дигиталну интеракцију са сензационалистичким медијским садржајима како би представила поразан утицај технологије и медија на културно и социјално (не)утемељену свест о силовању као злочину чија жртва може бити било ко, без обзира на родну и класну припадност.

Примамљива понуда нових технологија да нас одведу изван оквира емпиријске реалности наводи појединца да у жељи за променом заборави на ризике и прихвати преображене законитости фиктивног света, у ком јунаци почињу да на другачији начин трагају за изгубљеном синтезом љубави, наде и поверења. Јунаци напуштају офлајн свет како би у виртуелној димензији потражили одрживу илузију егзистенције.

КљУчНЕ РЕчИ: технологија; наратив; реализам; култура; медији.

Овај чланак је објављен и дистрибуира се под лиценцом Creative Commons Ауторство-Некомерцијално Међународна 4.0 (CC BY-NC 4.0 |

https://creativecommons.org/licenses/by-nc/4.0/).

This paper is published and distributed under the terms and conditions of the Creative Commons Attribution-NonCommercial International 4.0 licence (CC BY-NC 4.0 | https://creativecommons.org/licenses/by-nc/4.0/). 